\title{
Developing Integrated Triplet Multi-Representation Virtual Laboratory in Analytic Chemical Materials
}

https://doi.org/10.3991/ijim.v15i08.21573

\author{
Hayuni Retno Widarti $\left({ }^{凶}\right)$, Deni Ainur Rokhim, M. Muchson, \\ Endang Budiasih, Sutrisno, Rico Wahyu Pratama, Moh. Ilmanul Hakim \\ Universitas Negeri Malang, Malang, Indonesia \\ hayuni.retno.fmipa@um.ac.id
}

\begin{abstract}
Technological developments have triggered the emergence of various kinds of learning media innovations. Learning media is a very important part of the learning process. In this study, researchers designed a learning media in the form of a virtual laboratory on the practicum material of the basics of analytical chemistry which is integrated with multi-representation triplets to create and describe the results of learning media. The method used in this development was Research and Development (R\&D) method using the 4-D (four-D) development model. Data collection used qualitative and quantitative data. The results showed that the validation of the material obtained a percentage of $84 \%$ (very valid), media validation of $78 \%$ (valid), and the results of trials on correspondents obtained a percentage in the range $81-92 \%$ (very valid). It can be concluded that the virtual laboratory learning media on the analytical chemistry laboratory material with the integration of the developed multi-representation triplet explanations is feasible to use, especially in the practicum of the basics of analytical chemistry on the topic of group I cation analysis and argentometry. This shows that the virtual laboratory developed has the potential to support online practicum learning, and the macroscopic, submicroscopic, and symbolic depiction in the virtual laboratory can help the process of receiving information by students.
\end{abstract}

Keywords - Virtual Laboratory, Multiple Representation, Analytical Chemistry

\section{Introduction}

The use and application of information technology have grown rapidly. This has triggered the development of innovation in the field of education to integrate technology in order to improve the quality of education [1]. Facilities in technology allow the provision of material outside the classroom and application and/or feedback to take place in the classroom [2], especially in science material. One example of technology in science education is the use of software such as Moodle, Wiki, Edmodo, or other elearning media [3] that supports $21^{\text {st }}$ century skill acquisition [4]. The $21^{\text {st }}$ century is marked by the rapid development of science and technology so that science and technology are one of the important foundations in nation-building. One of the technolog- 
ical developments that underlie the development and advancement of science is chemistry. Chemistry is a branch of science that is very close to practicum activities in learning to provide meaningful learning experiences [5].

Practicum is an activity to provide understanding to students about a material. Students can understand and solve problems related to concepts taught in class and gain deep understanding through the scientific process [6] [7]. Practicum has a very important position to support the theoretical explanations that exist in chemistry learning [8]. Practical activities in chemistry learning are generally practicum types at the confirmative inquiry level that carry out practicum activities based on problems, procedures, analysis techniques, and data interpretation that have been prepared by the teacher in the form of a practicum manual [9]. Confirmative practicum is still often used because it can do a lot of practicum in a class with a large number of students with limited time and resources. Practical activities often begin with pre-practicum activities and end with post-practicum activities. Pre-practicum in the form of tests of students' understanding of the practicum that will be carried out and post-practicum in the form of evaluation and reflection. Without pre-practicum activities, student activity becomes low and practicum activities are just carried out [10]. This is related to the findings of the researchers 'observations that in practicum activities, the tendency of low prerequisite (initial) knowledge of students has an impact on low learning outcomes, thus encouraging research to increase students' initial knowledge. Thus, it is important to develop practicum learning with technology integration.

One of the chemical materials that require practicum to support student understanding is basic analytical chemistry studies. The scope of material includes qualitative analysis and quantitative analysis chemistry. One of the materials in qualitative chemistry is cation analysis and anion analysis, while in chemical analysis, quantitative analysis is related to titrimetric analysis, gravimetric analysis, and instrumentation analysis [11] [12]. In general, the practice of learning on analytical chemistry material is still limited to the order of verbal and practical explanations that are carried out to verify the expected results in the practicum module or by the teacher.

Based on the results of unstructured observations made on three teachers of SMKN 7 Malang in the chemical analysis program in 2020, one of the materials that are difficult to teach is qualitative analysis material in the cation analysis and titration chapters. This is because this material is factual, contains many concepts and procedures, especially in the form of chemical reaction equations. This finding was reinforced by Fathonah's research, which stated that learning outcomes on qualitative analysis chemistry tended to be low, and the results of the needs questionnaire distributed to 30 students of SMK Bhakti Mulia Wonogiri which showed that $53.33 \%$ of students chose qualitative analysis material as material that was difficult to understand [12]. Based on the results of the interview, information was also obtained that the limitations of tools and materials are another common obstacle in implementing practicum activities for these materials in schools. The use of practicum methods to teach argentometric titration material and cation analysis carried out at the SMK level is generally limited to basic studies. These activities do not provide experiences to students about the real conditions in detail. This results in students not having a complete understanding of the material, and the general procedure is that students cannot be crea- 
tive to experiment with other conditions or practice before carrying out practicum activities. In addition, practicum in the laboratory has not been able to support the sub-microscopic aspects, which are one of the demands in studying chemical materials such as argentometric titration and cation analysis.

Based on the constraints in implementing the practicum on this material, an alternative solution that can be done is to use virtual lab learning media that can help students understand the concept by performing practicum simulations. Efforts to develop practicum learning that are currently being studied are the integration of the use of information technology in the form of a virtual laboratory [13]. It is based on the premise that information technology provides an alternative learning environment that can contribute to meaningful learning [14]. In addition, previous research has been conducted by Dyrberg et al. [15] reports that learning preparation in practicum can be improved through the use of virtual laboratories as students become more confident and comfortable in doing practicum so that students' learning motivation increases. The use of virtual laboratories is proven to improve students' understanding [16], and can improve the thinking skills of students [17]. Therefore, it is important to develop a virtual laboratory, especially in the field of chemistry.

The virtual laboratory is a series of laboratory learning innovations in the form of software (software) to help students in pre-lab preparation, strengthen students' understanding of concepts, and as a substitute or complement to real labs because students can repeat practical simulations that are not understood. It is hoped that dense chemical materials such as argentometric titration will be easier to understand, especially in the basic concepts and techniques used in practicum using virtual labs.[18] [19]. In addition, the microscopic images presented in the virtual lab can be used to help students understand concepts [20].

The software can be developed so that it can be used flexibly and effectively on smartphones [21]. The use of smart telephones can make it easier for students to learn before carrying out practicum [22]. In practicum activities, the use of virtual laboratories provides a form of offering in the form of more educational applications, physical and chemical simulations assisted by computers/cell phones and copies of natural phenomena and experimental conditions [23]. Virtual laboratories can be used to acquire conceptual knowledge and develop science process skills [24]. Virtual laboratories were created as an additional medium to develop skills to conduct analytical experiments, and to develop the ability to interpret experimental results, especially during pre-lab lectures [5].

Virtual laboratories are very suitable to be developed for chemistry practicum activities, including studies from one of the branches of analytical chemistry. Based on the characteristics of the basics of analytical chemistry, skills are needed in using tools and practicum materials properly. The development of science and technology is the foundation of renewal in the revolutionary paradigm [25]. Under Liao et al., in this revolutionary era, America, France, and Italy were the best countries in terms of planning the development of the industrial revolution. The three countries invest in research and information, employment, education, training, and structural modernization. One of the investments that supports the progress of human civilization is education. In the development of this revolutionary era the world of education also contin- 
ues to make improvements in its system. As Shahroom and Hussin said, education in the future will experience significant changes [26]. The learning process no longer needs to be done in the classroom. Education in this digital revolution era demands the use of digital technology as a tool to improve academic quality [27], and virtual laboratory is one of the media that can be used in learning in this digital era, especially in practicum learning Therefore, this study developed virtual laboratory teaching materials with the aim of creating and describing the results of virtual laboratory learning media on the basics of analytical chemistry based on multiple representations. The development of virtual lab learning media is expected to increase competency attainment in chemistry learning for affective, cognitive, and psychomotor knowledge, and can attract learning interest for students to explore subject matter.

\section{Literature Review}

\subsection{Virtual laboratory}

Virtual laboratory is a computer-based media that students can use in doing virtual experiments [28]. In the virtual laboratory the tools and materials needed for the experiment are readily available on a computer program. As a learning media product, virtual labs provide opportunities for students to carry out a series of practical activities independently via computers or smart devices, either using the internet or without internet access [29].

The advantages of using a virtual laboratory were expressed by Dalgarno [30]. First, a virtual lab is used to demonstrate and provide chemical concepts to students in the form of visual representations. Second, virtual labs are used to prepare students for laboratory activities. This statement was corroborated by Herga's opinion [31] that the use of virtual labs that present visualization at the sub-microscopic level can act as a way to attract students' interest in learning a concept that is considered boring.

\subsection{Analytical chemistry and multiple representatives}

Analytical Chemistry is a branch of chemistry that studies theories and concepts and how to perform chemical analysis of a chemical substance or substance, which can include separation, identification, and determination of components in a sample. There are two types of chemical analysis, namely qualitative and quantitative, which can be applied to both organic and inorganic chemistry [32]. The qualitative analysis aims to state the presence of elements, ions, or compounds in a sample. In contrast, the quantitative analysis states the amount or how much of a certain substance is in the sample. The substance specified is called the desired constituent or analyte. While the amount of a certain substance in a sample is usually expressed as a concentration or concentration, for example, percent by weight, molar, grams per liter, or ppm [33] [34]

There are three aspects that must be understood in chemistry, namely macroscopic, microscopic, and symbolic (representational), including analytical chemistry. In the 
macroscopic aspect, it is a representation of chemistry that is obtained or observed through observation by the five senses. The microscopic aspect is a representation of chemistry that explains the structure and processes at the particle level or about the observed macroscopic phenomena, while the symbolic aspect represents the topic or concept of chemistry in the form of formula or symbol.

\section{Method}

This study employed Research and Development (R\&D) by adopting a 4-D (four D) development model. It produced a product in the form of a triplet-based virtual laboratory representation of the basics of analytical chemistry. Four- D is divided into a sequence of development stages from the define, design, develop, and disseminate stages Thiagarajan. However, the dissemination stage was not carried out when the research was carried out in April-June 2020 at the Chemistry Department, State University of Malang.

The development procedure which adopts the 4-D model is described as follows: 1) Define Stage which includes front-end analysis, learner analysis, task analysis, concept analysis, and specifying instructional objectives. At this stage, an analysis of basic problems is carried out based on the curriculum used and analyzes the character of students regarding analytical chemistry material, 2) Design stage which includes the selection of the media used, the format viewer or the design of the storyboard, and the initial design related to the components of the virtual laboratory media, 3) Develop Stage including expert validation. At this stage, five aspects were explored in the expert validation stage, including media format, language, media content, graphics, and aspects of media presence, as well as development trials conducted by legibility testing, and 4) Disseminate Stage covers empirical validation, packaging, deployment, and use. This stage was not conducted in the present study since the researchers encountered time and funding constraints.

Product testing was carried out with virtual laboratory validation and media legibility testing. Content validation is an assessment of the rater whose aim is to determine the feasibility of the product. Meanwhile, field trials or empirical validation were not carried out due to time and funding constraints. Virtual laboratory validation was carried out by providing instrument sheets to a lecturer in the chemistry department of State University of Malang. In the readability test, an assessment was carried out by students.

The subject of trying to validate is also known as a validator. The validator criteria for lecturers are 1) experience in guiding practicum activities, 2) mastering chemical materials, especially chemical separation, 3) understanding the guided inquiry learning model. Meanwhile, the validator criteria for students are chemistry students who are taking or have attended a basic class of analytical chemistry at the State University of Malang and are proficient in operating smart telephones. There are 25 student validators.

The data obtained will be in the form of qualitative and quantitative data. The explanatory items from the qualitative data are comments, suggestions, or criticisms 
from the validator. While the explanatory items from quantitative data are numbers obtained from filling out the validation instrument sheet for development products using a Likert scale $(5,4,3,2,1)$.[35]. The quantitative item analysis technique used is the average calculation technique proposed by Arikunto [36] as follows:

$$
\bar{X}=\frac{\sum X}{n}
$$

Under:

$\overline{\mathrm{X}}$ : average value

$\Sigma x$ : the number of answers to the validator / test subject assessment

n: number of validators

To find out the conclusions from the above average calculation results, a range of validation criteria is used. The range of validation criteria for the complete calculation results can be observed in Table 1 .

Table 1. Criteria for Validation Results

\begin{tabular}{|c|l|}
\hline Value & \\
\hline $0-20 \%$ & Criteria \\
\hline $20-40 \%$ & Poor Poor \\
\hline $40-60 \%$ & Average \\
\hline $60-80 \%$ & Good \\
\hline $80-100 \%$ & Very Good \\
\hline
\end{tabular}

\section{$4 \quad$ Results and Discussion}

\subsection{The developed model}

The virtual laboratory application developed by this researcher is named Inter-Val: Interactive Virtual Analytical Laboratory. The virtual laboratory application was developed on analytical chemistry lab material, namely Cation Analysis Group I and Argentometry material. This virtual laboratory application was developed by integrating multiple representations or triplet representations. This developed application is operated using a smartphone so that it can be accessed easily anytime and anywhere. As it is known, smartphones are items that are always there and taken anywhere without exception by students. Researchers developed this application in order to make practical learning media innovations that can overcome problems or things that cannot be found in real practicum activities so that this product can be used to overcome these problems. The results of the virtual laboratory application development are presented to the figure 1 , figure 2 , and figure 3 . 
1. The initial view of the application

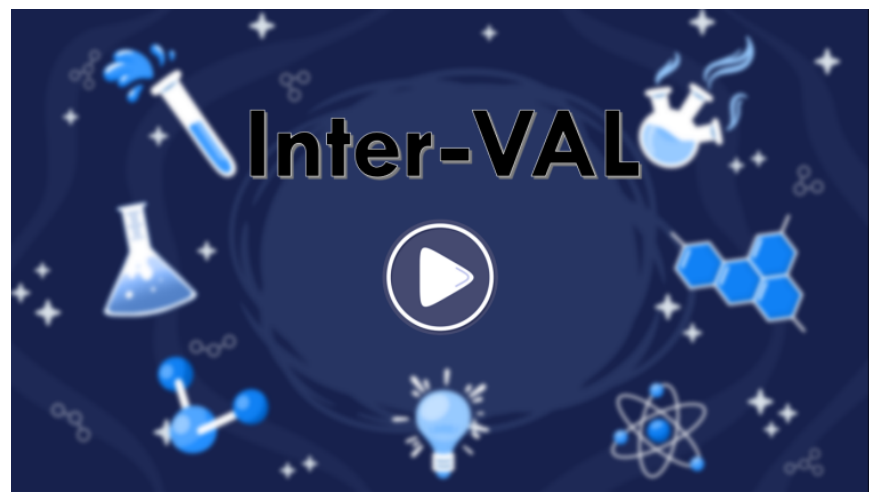

Fig. 1. Application start view

2. Display the menu of the virtual laboratory application. In this display, there are five menus, namely pretest, posttest, virtual lab, materials, and glossary.

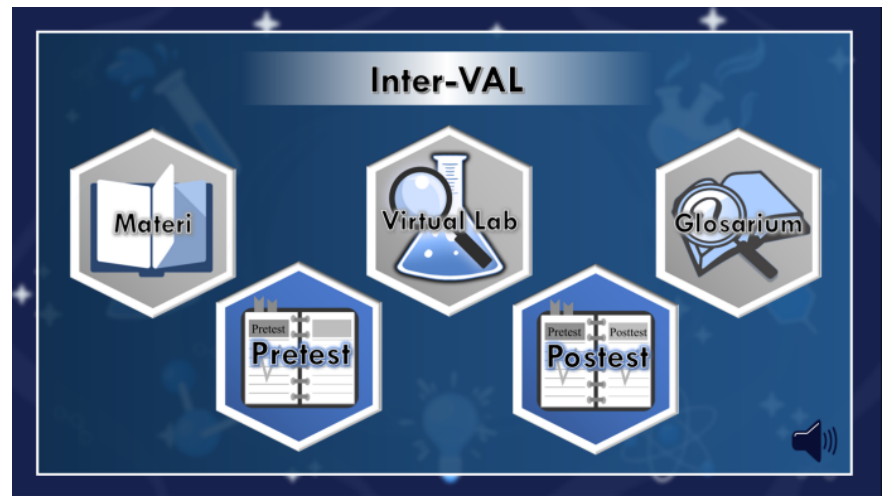

Fig. 2. Application menu display

Based on research Dwiningsih stated that the results of the approval questionnaire used virtual laboratory learning media in the chemistry learning process given to students showed a percentage of $80 \%$ agreed that the chemistry learning process was carried out using virtual laboratory learning media, besides the observation results of students' activities in using laboratory learning media virtual get a percentage of $88.75 \%[13]$.

Virtual laboratory learning media in the learning process provides students the opportunity to further explore their respective knowledge, which allows students to always be active and not only record or listen to what the teacher says. [37]. The virtual laboratory can significantly influence the learning motivation of students [38]. As expressed by Jaya in his research, practicum activities in laboratories that are interactive, dynamic, animative can be supported by the existence of a virtual laboratory. 
[39]. The development of a virtual laboratory is very suitable for chemistry practicum activities, especially in the branch of analytical chemistry [22]. Virtual laboratories can train students to improve critical thinking [40].

Virtual chemistry laboratories provide both students and teachers with potential as an educational tool enabling them to introduce new strategies to support higher-level skills such as communication and information literacy, self-management knowledge skills, problem-solving, independent learning, and cooperative learning. [41]. The virtual laboratory has a positive impact on the learning motivation of students [42].

The virtual laboratory in learning chemistry has many benefits, as expressed by Dalgarno et al., [43] that with a virtual laboratory students will feel more relaxed and comfortable in the laboratory, do not spend time looking for the equipment used, and students can devote more of their attention to the chemical concepts involved in an experimental process.

The multi-representation explanation in the virtual laboratory is the advantage of the product developed by the researcher. With the multi-representation explanation, students can observe the experimental process from a macroscopic, symbolic, and microscopic point of view that cannot be observed in a real laboratory lab. These advantages can help improve students' understanding of the process of practicum activities, especially in analytical chemistry practicum. This is supported by a statement N. R. Herga \& D. Dinevski in his research which states that virtual laboratories can be used for learning chemistry because they allow the integration of three levels of representation of chemical science understanding through visualization and simulation processes [41].

Multi representation is an important component of learning chemistry. It takes a deeper understanding of studying chemistry, because chemistry is a very abstract science. With the multi representation explanation in the virtual laboratory, students are helped in understanding the concepts of chemistry, especially in analytical chemistry. As expressed by (Hasibuan, et al., 2018) in his research that the explanation of the three levels of representation in chemistry can describe abstract material and help find a concept so that it makes it easier for students to learn it [44].

This virtual laboratory cannot replace practicum activities that are carried out directly in the laboratory. This is evidenced by the results of research conducted by (Dewi et al., 2019) that there are differences in the learning outcomes of students who are taught with virtual laboratories with students who are taught using real laboratories. It was found that students who were taught real practicum had better learning outcomes than students who were taught with virtual laboratories. [45]. However, apart from that this virtual laboratory can provide an overview to students regarding the practicum that is being carried out. In addition, with the multi-representation explanation in this virtual laboratory, students can observe an experimental process from a macroscopic, symbolic, and microscopic perspective that cannot be observed in a real laboratory practicum. So, the existence of this virtual laboratory will be very helpful and accompany students in learning chemistry, especially learning analytical chemistry. It is stated that virtual laboratory is an alternative application to a real laboratory when an experiment cannot be done for several reasons [42]. 


\subsection{Developed android-based teaching materials}

Virtual laboratory, as one of the digital applications in the Android version, has several specifications, namely, used on smartphones with the Android Operating System (OS), landscape display in 2D (two-dimensional), providing a triplet representation and interactive explanation. This virtual laboratory application can be used to accompany practical activities both before, after, and even during the learning activities of the analytical chemistry practicum in the laboratory. Before the practicum can be used to do a pretest, the results will be automatically sent to the teacher's email. After practicum, it can be used to do a posttest to evaluate students after practicum activities. When practicum activities can be used to observe material about practicum that will be carried out an/ or explanation of phenomena in terms of three levels of representation, especially submicroscopic phenomena that cannot be seen with the naked eye while doing real practicum activities in the laboratory which aim to help students understand the results a practicum process that is carried out.

This virtual laboratory application presents two practical material topics that can be done by students on the virtual lab menu, namely class I cation analysis material and argentometry. In the virtual lab menu, several components are presented that support practical activities, starting from experimental procedures, tools, materials, and explanation of 3 levels of representation. Students can do a practicum in accordance with the procedures provided and choose their own tools and materials used, then take actions starting from reacting to the materials and so on by pressing the "do" button as shown in Figure 3.

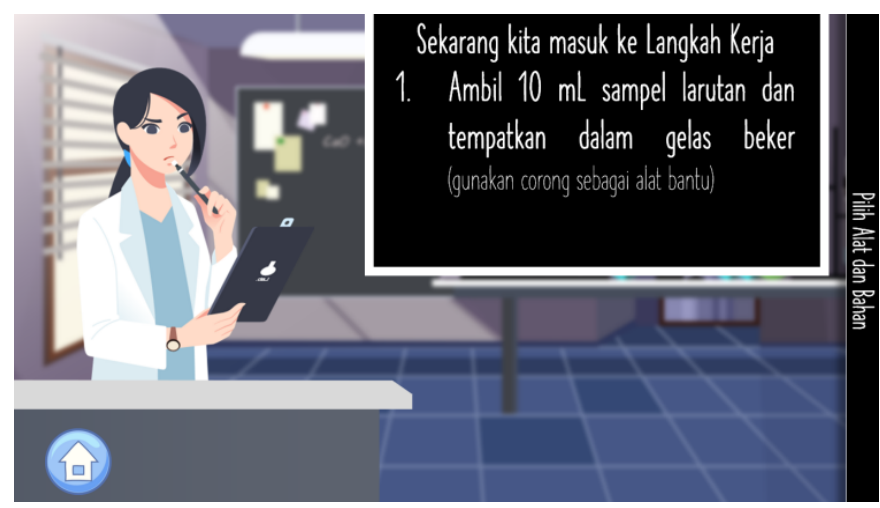

a) Procedures 


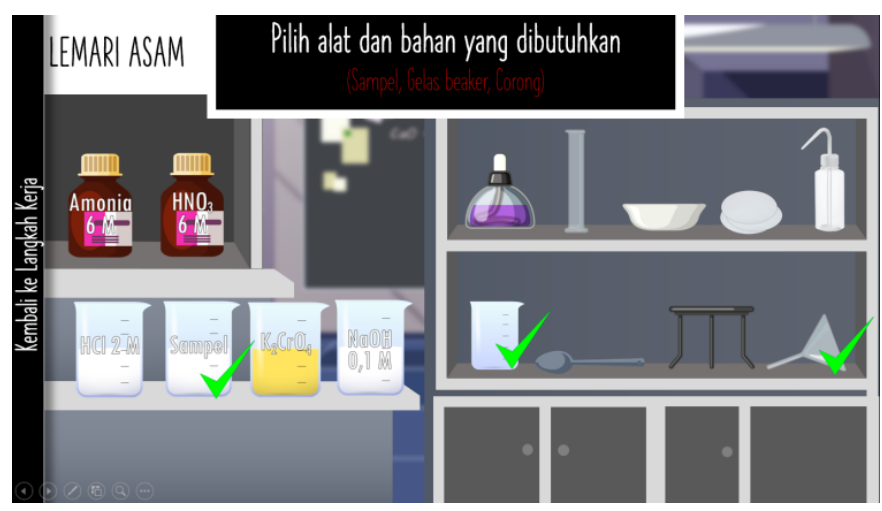

b) Tools and Materials

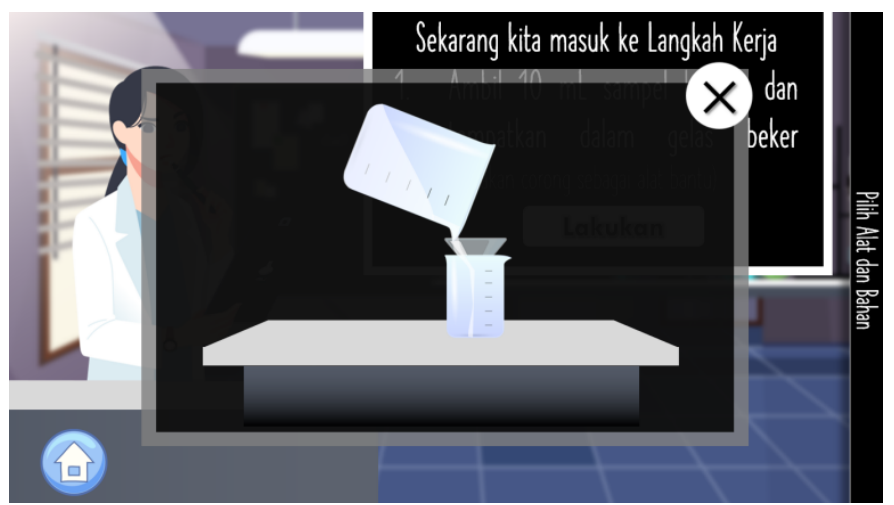

c) Lab actions

Fig. 3. Virtual lab menu display

There are several provisions in this virtual laboratory application, namely on the material menu: contains practicum material that can be used for students as a source of knowledge related to the practicum that will be done, on the pretest menu: contains practice questions before doing practicum as information on students' prior knowledge before doing practicum activities, on the posttest menu; contains practice questions as an evaluation of students after doing practicum activities, on the virtual lab menu: contains practicum activities consisting of tools, materials, experimental procedures, and an explanation of 3 levels of representation, on the glossary menu: contains important words or terms related to practicum analytical chemistry. Menus in V-lab can be operated automatically by pressing the available buttons. The button will take the user to the page to be addressed or desired. The V-lab developed will be connected to the teacher's email, for example, when students access pretest and postest questions. The results of the students' work will be known by the teacher with a system that has been set, so that there is interaction through the application developed between the teacher and students. The components or aspects in this developed application will 
certainly continue to experience developments in line with existing technological developments, so that great benefits can be felt by education units, especially in chemistry practicum activities.

\subsection{Validation results}

In the validation stage, it was carried out by 2 chemistry lecturers of State University of Malang, who are experts in analytical chemistry and experts in learning media. This validation stage is carried out to ensure that the learning media developed is in accordance with the principles of analytical chemistry as it should be. Besides this validation also ensures that the learning media developed meets the feasibility of being used by students based on the opinions of experts.

At this validation stage, there are two criteria that are assessed, namely in terms of material and media. The instruments used were the material validation questionnaire sheet and the media validation questionnaire sheet containing a statement of aspects adjusted to the judge. The ranges used on this validation questionnaire are numbers 1 to 5 , where number 1 shows the criteria are not good, unclear, inappropriate, and unattractive. Number 2 shows the criteria are not good, unclear, less suitable, less attractive, number 3 indicates criteria such as good enough, clear enough, sufficiently appropriate, and quite interesting. Number 4 indicates good, clear, appropriate, interesting criteria, and number 5 indicates very good, very clear, very appropriate, and very interesting criteria. In addition, comments and suggestions are also presented on each validation sheet.

Based on the validation results of the material validator, a value of $84 \%$ was obtained, which means that the material is classified as very valid and suitable for use without the need for revision because the validation results assessment points have reached numbers in the range of average values 81-100 based on the criteria table. Validation results (Arikunto, 2010) and the products produced in this study can be used directly to assist and assist in the learning process of analytical chemistry practicum on group I cation analysis material and argentometry material. However, it will still be improved based on suggestions and comments from the validator, such as adding concepts about analytical chemistry, and adding pretest and posttest questions, so that the resulting product becomes a perfect product. Meanwhile, based on the results of the media validator, a percentage value of $78 \%$ was obtained, which means that the media developed is classified as valid because the assessment points of the validation results have reached numbers in the average value range of 61-80 based on the validation results criteria table. (Arikunto, 2010) and the products produced in this study, the media display design has met the requirements in terms of media format, language, media content, graphics, and aspects of media presence, so that the product can be used. This analytical virtual laboratory learning media product will still be revised in accordance with the suggestions and comments that have been given by the validator on the media validation questionnaire to improve the media components developed. Besides, this revision of media products is also carried out to achieve a very valid learning media category. These comments and suggestions help researchers in perfecting the learning media products being developed. 


\subsection{Readability test}

Respondents involved in this study were 25 chemistry students of State University of Malang. At the point of media presentation, the aspects assessed are the ease of understanding the language, the combination of colors, the shape and size of the text, and the attractiveness of the appearance or design of the media. The validation results showed $84 \%$. At the point of information clarity, the aspects assessed are the ease of operating the media, the ease of understanding practicum instructions, the ease of understanding practicum activities, the ease of understanding pretest and posttest questions, and the ease of understanding the material through the help of pictures and animation. The validation results showed $88 \%$. At the point of use of the program, the aspects assessed were the ease of running pretest and posttest questions, the ease of running practicum simulations, and the interest in doing a practicum. The validation results showed $81 \%$. At the point of the effectiveness of the media, the aspect assessed is the ability of the application to increase learning motivation and use it independently. The validation result showed $92 \%$.

Based on the interpretation of the validation result scores, the virtual laboratory application in terms of presentation is categorized as very valid because the value ranges from $81-92 \%$. This shows that from the user's point of view, all instructions and guidelines for practicum procedures in the media can be understood properly, the selection of diction and color combinations of letters with the background is correct, and can increase learning motivation. Virtual laboratory is a visual-based learning media that has a function as a tool in learning activities so as to create a better learning environment. The use of learning media can arouse student interest and motivation. This interest provides a great opportunity to achieve learning goals [46].

\subsection{The developed virtual laboratory for online learning media}

Virtual laboratory can be operated using an android smartphone. The advantage of an Android device is that it can facilitate online learning because it can be used as a synchronous and asynchronous communication tool anytime and anywhere. These advantages can increase learning outcomes while saving education costs.

Virtual laboratory allow students to carry out practical work indirectly or without entering the real laboratory. The urgency of online learning includes 1) the Covid-19 pandemic, which makes all activities, including learning activities to be carried out without face to face, 2) the cost of providing raw materials for expensive practicum activities, and 3) demands the use of technology in education. With a virtual laboratory, students can carry out practical activities like practicum in a laboratory.

The developed virtual laboratory has the potential to be used for learning without face-to-face or online. The following are some of the potential virtual laboratories that have been developed as follows: 
1. Supporting online practicum learning. This is very useful because during the pandemic, practicum learning tends to be hampered, so the use of a virtual laboratory is used

2. Students can learn and do independent practicum activities at home

3. Macroscopic, submicroscopic, and symbolic depictions in a virtual laboratory can help the process of receiving information by students

4. Online scoring or assessment. Question assessment and job submissions can be done online and sent via email to the teacher. So that the teacher can see the total value acquisition or value recapitulation along with the work of students

5. Material for group I cation separation and the argentometric titration is available in the application so that students can access and study material from anywhere and anytime

Some of the shortcomings in virtual laboratories that have been developed and do not support online learning are as follows.

1. The teacher cannot observe the practical implementation directly

2. Practical experience obtained by students is lacking

3. Students will be difficult to guide if there is no awareness and desire to learn

\section{Conclusion}

This study has indicated that the virtual laboratory on argentometry material and the separation of class I have a positive impact on online learning. This is supported by the acquisition of a development validation score of $84 \%$ for material validation and $78 \%$ for media validation. This score indicates that the virtual laboratory is very valid in material validation and valid on media validation. Based on the validation results, the suitability of argentometric material and the separation of class I cations in the virtual laboratory are correct and only need some improvements in the appearance of the media according to the advice of the validator. Meanwhile, the virtual laboratory readability test scores in the range $81-92 \%$ which makes the media very valid. This shows that from the readability point of view, the media can be understood clearly and have used the right word choice. Weaknesses in virtual laboratories can be minimized with policies, commitments, and further product development so that they can be focused on online learning media in practicum activities.

\section{References}

[1] C. A. M. Rahmani, Haryono, and E. Purwanti, "Pengembangan Media Komunikasi Buku Penghubung Berbasis SMS Gateway dan Mobile Web,” Innov. J. Curric. Educ. Technol., vol. 6, no. 2, 2017.

[2] J. M. Esson, "Flipping General and Analytical Chemistry at a Primarily Un-dergraduate Institution," in The Flipped Classroom Volume 2: Results from Practice, vol. 1228, American Chemical Society, 2016, pp. 107-125 SE-7. https://doi.org/10.1021/bk-2016$\underline{1228 . \operatorname{ch} 007}$ 
[3] R. Franklin and J. Smith, "Practical assessment on the run: iPads as an effective mobile and paperless tool in physical education and teaching," Res. Learn. Technol., 2015, https://doi.org/10.3402/rlt.v23.27986

[4] F. Kimianti and Z. K. Prasetyo, "Pengembangan E-modul IPA Berbasis Prob-lem Based Learning untuk Meningkatkan Literasi Sains Siswa,” Kwangsan J. Teknol. Pendidik., vol. 07, no. 02, pp. 91-103, 2019. https://doi.org/10.31800/jtp.kw.v7n2.p91--103

[5] B. Bortnik, N. Stozhko, I. Pervukhina, A. Tchernysheva, and G. Belysheva, "Effect of virtual analytical chemistry laboratory on enhancing student re-search skills and practices," Res. Learn. Technol., vol. 25, no. 1063519, pp. 1-20, 2017, https://doi.org/10.25304/ rlt.v25.1968

[6] J. Lang, "Comparative study of hands-on and remote physics labs for first year university level physics students," Transform. Dialogues Teach. Learn. J., vol. 6, no. 1, pp. 1-25, 2012.

[7] H. Makransky, G., Thisgaard, M. W. \& Gadegaard, "Virtual simulations as preparation for lab exercises: Assessing learning of key laboratory skills in microbiology and improvement of essential non-cognitive skills," PLoS One, vol. 11, no. 6, pp. 1-11, 2016, https://doi.org/10.1371/journal.pone.0155895

[8] A. Kurbanoglu, N.I. \& Akim, "The relationships between university students' chemistry laboratory anxiety, attitudes, and self-efficacy beliefs," Aust. J. Teach. Educ., vol. 35, no. 8, pp. 48-59, 2010, https://doi.org/10.14221/ajte.2010v35n8.4

[9] M. Buck, L.B., Lowery Bretz, S., and Towns, "Characterizing the level of inquiry in the undergraduate laboratory,” J. Coll. Sci. Teach., vol. 38, pp. 52-58, 2008.

[10] A. J. Cann, "Increasing Student Engagement with Practical Classes Through Online PreLab Quizzes," J. Biol. Educ., vol. 50, no. 1, pp. 100-111, 2016, https://doi.org/10. $\underline{1080 / 00219266.2014 .986182}$

[11] E. Budiasih and D. Sukarianingsih, "Peningkatan Kualitas Pembelajaran Matakuliah Dasar-Dasar Kimia Analisis Melalui Strategi Think Pair Share (Tps) Dengan Pengorganisasian Pembelajaran Menurut Teori Elaborasi,” J. Pembelajaran Kim., vol. 1, no. 2, pp. 19-31, 2016. https://doi.org/10.33369/pgsd.11.2.165-169

[12] R. Fathonah, M. Masykuri, and S. Saputro, "Pengembangan Multimedia Simulatif Kimia Berbasis Inkuiri Terbimbing pada Materi Analisis Kualitatif Kation Golongan 1,” J. Inkuiri, vol. 4, no. 3, pp. 2252-7893, 2015. https://doi.org/10.20961/inkuiri.v8i2.31822

[13] D. Chemical, I. Media, U. Virtual, and K. Dwiningsih, "Pengembangan Media Pembelajaran Kimia Menggunakan Media Laboratorium Virtual Berdasarkan Paradigma Pembelajaran Di Era Media based on the Global Era Learning Paradigm," vol. 06, no. 02, pp. 156176,2018.https://doi.org/10.31800/jtp.kw.v6n2.p156-176

[14] A. I. Gambari, H. Kawu, and O. C. Falode, "Impact of virtual laboratory on the achievement of secondary school chemistry students in homogeneous and heterogeneous collaborative environments," Contemp. Educ. Technol., vol. 9, no. 3, pp. 246-263, 2018, https://doi.org/10.30935/cet.444108

[15] N. R. Dyrberg, A. H. Treusch, and C. Wiegand, "Virtual laboratories in science education: students' motivation and experiences in two tertiary biology courses," J. Biol. Educ., vol. 51, no. 4, pp. 358-374, 2017, https://doi.org/10.1080/00219266.2016.1257498

[16] T. Darby-white, S. Wicker, and M. Diack, "Evaluating the Effectiveness of Virtual Chemistry Laboratory (VCL) in Enhancing Conceptual Understand-ing: Using VCL as PreLaboratory Assignment,” J. Comput. Math. Sci. Teach., vol. 38, no. 1, pp. 31-48, 2019.

[17] A. Widowati, S. Nurohman, and D. Setyowarno, "Development of Inquiry-Based Science Virtual Laboratory for Improving Student Thinking Skill of Junior High School," J. Pendidik. Mat. dan Sains, vol. 5, no. 2, pp. 170-177, 2017, doi: 10.21831/jpms.v5i2.16708. 
[18] R. Jagodzinsky, P. \& Wolski, "Assesment of application technology of natu-ral user interfaces in the creation of a virtual chemical laboratory," J. Sci. Educ. Technol., vol. 24, no. 1, pp. 16-28, 2015, https://doi.org/10.1007/s10956-014-9517-5

[19] M. S. C. Jiménez, P.M., Pedrajas, A.P., Polo, J., \& Bellido, "Learning in chem-istry with virtual laboratories," J. Chem. Educ., vol. 80, no. 3, pp. 346-352, 2003, doi: 10.1021/ed080p346. https://doi.org/10.1021/ed080p346

[20] M. Muchson, M. Munzil, B. E. Winarni, and D. Agusningtyas, "Pengem-bangan Virtual Lab Berbasis Android,” J-PEK (Jurnal Pembelajaran Kim., vol. 4, no. 1, pp. 51-64, 2019. https://doi.org/10.17977/um026v4i12019p051

[21] Manikowati and D. Iskandar, "Pengembangan Mobile Virtual Laboratorium untuk Pembelajaran Praktikum SIswa SMA," Kwangsan J. Teknol. Pendidik., vol. 06, no. 01, pp. 2342, 2018, https://doi.org/10.31800/jtp.kw.v6n1.p23--42

[22] D. Rokhim, M. Asrori, and H. Widarti, "Pengembangan Virtual Laboratory Pada Praktikum Pemisahan Kimia Terintegrasi Telefon Pintar,” JKTP J. Kaji. Teknol. Pendidik., vol. 3, no. 2, pp. 216-226, 2020, https://doi.org/10.17977/um038v3i22020p216

[23] Z. Tatli and A. Ayas, "Effect of a Virtual Chemistry Laboratory on Students' Achievement," Educ. Technol. Soc., vol. 16, no. 1, pp. 159-170, 2013.

[24] M. E. Peffer, M. L. Beckler, C. Schunn, M. Renken, and A. Revak, "Science Classroom Inquiry (SCI) simulations: A novel method to scaffold science learning," PLoS One, vol. 10, no. 3, pp. 1-14, 2015, https://doi.org/10.1371/journal.pone.0120638

[25] A. Liao, Y., Loures, E. R., Deschamps, F., Brezinski, G., \& Venâncio, "The Impact of The Fourth Industrial Revolution: a Cross-Country/Region Com-parison,” Prod. Prod., vol. 28, pp. 1-18, 2018. https://doi.org/10.1590/0103-6513.20180061

[26] A. A. Shahroom and N. Hussin, "Industrial Revolution 4.0 and Education," Int. J. Acad. Res. Bus. Soc. Sci., vol. 8, no. 9, pp. 314-319, 2018, doi: 10.6007/ijarbss/v8-i9/4593.

[27] Syamsuar and Reflianto, "Pendidikan dan Tantangan Pembelajaran Ber-basis Teknologi Informasi di Era Revolusi Industri 4.0," E-Tech J. Ilm. Teknol. Pendidik., vol. 6, no. 2, 2018.

[28] A. Adita and T. Julanto, "Penyusunan Virtual Laboratory Sebagai Media Pembelajaran Biologi," J. Penelit. dan Pengabdi. Kpd. Masy., vol. 3, no. 2, pp. 69-73, 2016.

[29] M. Khairudin, A. K. Triatmaja, W. J. Istanto, and M. N. A. Azman, "Mobile virtual reality to develop a virtual laboratorium for the subject of digital engi-neering," Int. J. Interact. Mob. Technol., vol. 13, no. 4, pp. 79-95, 2019, https://doi.org/10.3991/ijim. $\underline{\mathrm{v} 13 \mathrm{i} 04.10522}$

[30] B. Dalgarno, A. G. Bishop, A. Adlong, and D. R. B. Jr, "Effectiveness of a virtual laboratory as a preparatory resource for distance education chemistry students," Comput. Educ., vol. 53, no. 3, pp. 853-865, 2009. https://doi.org/10.1016/j.compedu.2009.05.005

[31] N. R. Herga, "Virtual Laboratory in the Role of Dynamic Visualisation for Better Understanding of Chemistry in Primary School," Eurasia J. Math. Sci. Technol. Educ., vol. 12, no. 3, pp. 593-608, 2016, https://doi.org/10.12973/eurasia.2016.1224a

[32] S. Darsati, "Ruang Lingkup Kimia Analitik dan Penggolongan Analisis Kimia," 2010, pp. $1-39$.

[33] G. Christian, Analytical Chemistry, 5th ed. New York: John Wiley \& Sons, 1994.

[34] F. J. Skoog, D.A., West, D.M., and Holler, Fundamentals of Analytical Chem-istry, 7th ed. New York: Saunders College Publishing, 1996.

[35] S. Rahayu, "Evaluating the Affective Dimension in Chemistry Education," in Affective Dimensions in Chemistry Education, 2015, pp. 29-49. https://doi.org/10.1007/978-3-66245085-7 2

[36] S. Arikunto, Prosedur Penelitian Suatu Pendekatan Praktek. Jakarta: Rineka Cipta, 2010. 
[37] A. Swandi, S. Nurul, H. Lj, and A. M. Pembelajaran, "Pengembangan Media Pembelajaran Laboratorium Virtual untuk Mengatasi Miskonsepsi Pada Ma-teri Fisika Inti di SMAN 1 Binamu, Jeneponto,” vol. XVIII, no. April, pp. 20-24, 2014.https://doi.org/10.22146/ jfi.24399

[38] W. C. Adi and M. Iqbal, "Virtual Laboratory," vol. 4, no. 4, pp. 130-136, 2016.

[39] H. Jaya, "Pengembangan laboratorium virtual untuk kegiatan paraktikum dan memfasilitasi pendidikan karakter di SMK," J. Pendidik. Vokasi, vol. 2, no. 1, pp. 81-90, 2013, https://doi.org/10.21831/jpv.v2i1.1019

[40] A. Lutfi, "Pengembangan Media Laboratorium Virtual Bersarana Komputer untuk Melatih Berpikir Kritis pada Pembelajaran Asam, Basa, dan Garam," J. Penelit. Pendidik. Mat. dan Sains Unesa, vol. 1, no. 1, pp. 27-33, 2017.https://doi.org/10.26858/cer.v0i1.5604

[41] N. R. Herga and D. Dinevski, "Virtual Laboratory in Chemistry - Experi-mental Study of Understanding, Reproduction and Application of Acquired Knowledge of Subject' s Chemical Content," vol. 45, no. 3, pp. 108-116, 2012, https://doi.org/10.2478/v10051012-0011-7

[42] C. Tüysüz, "The effect of the virtual laboratory on students' achievement and attitude in chemistry,” Int. Online J. Educ. Sci., vol. 2, no. 1, pp. 37-53, 2010, doi: 13092707.

[43] B. Dalgarno, A. G. Bishop, and R. Bedgood, "The potential of virtual labora-tories for distance education science teaching: Reflections from the develop-ment and evaluation of a virtual chemistry laboratory," Proc. Aust. Conf. Sci. Math. Educ. (formerly UniServe Sci. Conf., pp. 90-115, 2012.

[44] I. Ilmiah, P. Mahasiswa, M. P. Hasibuan, and R. P. Sari, "Penerapan Kompe-tensi Kimia SMA Menggunakan Pendekatan Pendidikan Kimia Pendahuluan Ilmu Pengetahuan Alam (IPA) berkaitan dengan cara mencari tahu tentang gejala alam secara sistematis, sehingga IPA bukan hanya penguasaan kum-pulan pengetahuan yang berup," vol. 1, no. 2, 2018. https://doi.org/10.21009/jrpk.011.01

[45] A. Dewi, N. Tika, and I. N. Suardana, "Komparasi Praktikum Riil Dan Prak-tikum Virtualterhadap Hasil Belajar Kimia Siswa Sma Pada Pembelajaran Larutan Penyangga,” J. Pendidik. Kim. Indones., vol. 3, no. 2, p. 85, 2019, https://doi.org/10.23887/jpk.v3i2.21236

[46] A. Purnomo, N. Ratnawati, and N. F. Aristin, "Pengembangan Pembelajaran Blended Learning Pada Generasi Z," J. Teor. dan Praksis Pembelajaran IPS, vol. 1, no. 1, pp. 7076, 2016, https://doi.org/10.17977/um022v1i12016p070

\section{Authors}

Hayuni Retno Widarti is a lecturer in chemistry in the field of analytical chemistry in the Department of chemistry, Faculty of mathematics and natural sciences, State University of Malang. Email: hayuni.retno.fmipa@um.ac.id

Deni Ainur Rokhim is a teacher at senior high school in sidoarjo, in the field of learning chemistry.

M. Muchson is a lecturer in chemistry in the field of learning media of chemistry, Faculty of mathematics and natural sciences, State University of Malang.

Endang Budiasih was a lecturer in chemistry in the field of analytical chemistry in the Department of chemistry, Faculty of mathematics and natural sciences, State University of Malang. 
Sutrisno is a lecturer in chemistry in the field of physical chemistry in the Department of chemistry, Faculty of mathematics and natural sciences, State University of Malang.

Rico Wahyu Pratama is an undergraduate student majoring in chemistry, Faculty of mathematics and natural sciences, State University of Malang.

Moh Ilmanul Hakim is an undergraduate student majoring in chemistry, Faculty of mathematics and natural sciences, State University of Malang.

Article submitted 2021-01-26. Resubmitted 2021-02-24. Final acceptance 2021-02-25. Final version published as submitted by the authors 